\title{
JURNAL BIOMEDIKA
}

Volume 13 No. 02 September 2020

P-ISSN: 1979 - 035X (printed) \& E-ISSN: 2302 - 1306 (online)

DOI: https://doi.org/10.31001/biomedika.v13i2.842

\section{Prevalence of Listeria spp. with PRS Genes in Fresh Vegetables from Traditional Markets}

\section{A. Kaisar Adiwijaya Putra*1, Rizalinda Sjahril ${ }^{2}$, Arif Santoso ${ }^{3}$, Dianawaty Amiruddin ${ }^{4}$, Andi Alfian Zainuddin 5 , Firdaus Hamid ${ }^{2}$}

${ }^{1}$ Department of Biomedical Science, Postgraduate Program, Universitas Hasanuddin Makassar

Jl. Perintis Kemerdekaan KM.10, Tamalanrea Indah, Tamalanrea, Makassar, Sulawesi Selatan, 90245 INDONESIA

${ }^{2}$ Department of Microbiology, Faculty of Medicine, Universitas Hasanuddin

Jl. Perintis Kemerdekaan KM.10, Tamalanrea Indah, Tamalanrea, Makassar, Sulawesi Selatan, 90245 INDONESIA

${ }^{3}$ Department of Pulmonology, Faculty of Medicine, Universitas Hasanuddin

Jl. Perintis Kemerdekaan KM.10, Tamalanrea Indah, Tamalanrea, Makassar, Sulawesi Selatan, 90245 INDONESIA

${ }^{4}$ Department of Parasitology, Faculty of Medicine, Universitas Hasanuddin

J1. Perintis Kemerdekaan KM.10, Tamalanrea Indah, Tamalanrea, Makassar, Sulawesi Selatan, 90245 INDONESIA

${ }^{5}$ Departmet of Public Health, Faculty of Medicine, Universitas Hasanuddin

Jl. Perintis Kemerdekaan KM.10, Tamalanrea Indah, Tamalanrea, Makassar, Sulawesi Selatan, 90245 INDONESIA

\section{ARTICLE INFO ABSTRACT}

Article History:

Received: July, 2020

Revise: December, 2020

Accepted: February, 2021

Keywords:

fresh vegetables; Listeria

spp.; multiplex PCR; prs

gene
Listeriosis is a foodborne infectious disease caused by Listeria monocytogenes and is considered a serious health problem, due to the severity of symptoms and a high mortality rate in worldwide This study aims to identify and determine the prevalence of Listeria species through prs gene screening of fresh vegetables distributed in several markets of Makassar City. A total of 57 fresh vegetable samples were collected from February to May 2019 in four traditional markets Makassar. The isolates is examines to phenotypically and genotypically Vitek and Multiplex PCR with prs and lmo1030 primer. Phenotype analysis did not show the presence of Listeria species, but the results of genotypic was found 8 positive prs gene samples $(14.03 \%)$, consisting of $31.2 \%$ long beans, $18.2 \%$ cabbage, and $9.1 \%$ cucumber and. All Listeria species found in this study is Listeria monocytogenes. This study also provide information and additional data that prs genes can be used as screening genotype for identify Listeria species in fresh vegetables.

\footnotetext{
*Corresponding author:

A. Kaisar Adiwijaya Putra

Department of Biomedical Science, Postgraduate Program, Universitas Hasanuddin Makassar

Email: adiwijayakaisar@gmail.com
} 


\section{INTRODUCTION}

Listeriosis is a foodborne infectious disease caused by Listeria monocytogenes and is considered a serious health problem, due to the severity of symptoms and a high mortality rate in worldwide. Recently, other Listeria species have been linked to diseases in humans and animals(Mazza R., et al, 2015). Most cases of human Listeria monocytogenes are associated with consumption of raw foods (European Food Safety Authority, 2013). Listeria monocytogenes is a pathogen that is transmitted through food, widely distributed in food ingredients such as vegetables, fruits, dairy products, and processed foods. Consumption of contaminated raw food and cooked half-cooked can cause listeriosis (Dandapani S., et al, 2011).

The results of the study of Jamali H. et al. (2013), showed that from the samples examined, $17.9 \%$ of ready-to-eat food samples contained Listeria spp. where $11.4 \%$ of the results were identified as Listeria monocytogenes. Although the incidence of listeriosis in humans in Indonesia has not been found, but the presence of Listeria monocytogenes in food has been reported such as fresh milk in South Sulawesi (Prahesti K.I. et al, 2017) and fresh chicken meat in West Java (Sugiri Y.D. et al., 2014). Approximately 1600 cases caused by are reported, including 255 cases of death each year in the United States (Scallan, et al., 2011). Therefore, the outbreak associated Listeria $s p p$. is a public health disease of concern.

The standard method widely used for determining Listeria spp. is the culture method, enrichment in liquid media and then isolation on solid selective media (Barocci, et al., 2008 but this method is considered to require a long time and some of the media used are fairly expensive. According to Aznar R. and Alarcón B. (2003), detection of Listeria monocytogenes in food samples is difficult because of the low bacterial count., so the genotype method using PCR can be a more effective and faster in diagnosis than others. The prs gene that encodes the putative phosphoribosyl pyrophosphate synthetase protein is a gene specific to Listeria spp. (Doumith M, et al, 2004)
Mortality rate of Listeria monocytogenes has been reported in high percentation (30\%), the presence of this bacterium in food consumption is an one of the major health problem such as meat, dairy, fish and vegetable products (Pesavento G., et al, 2010). The objective of our study was to determine the prevalence of Listeria spp. and rapid identification through prs gene screening of fresh vegetables.

\section{MATERIALS AND METHODS}

\section{Population and Sample}

The population in this study is food in the form of vegetables sold in Makassar traditional markets as a distribution point of vegetables from farmers with minimal decontamination processes. The samples used in this study were vegetables, namely cabbage (Brassica oleracea), lettuce (Lactuca sativa), cucumber (Cucumis sativus), basil (Ocimum citriodorum), and long beans (Vigna unguiculata). The number of samples used was 57 samples with a sampling technique based on purposive sampling, where the materials that meet the inclusion criteria is from traditional markets and the exclusion is non-decaying materials will be used as samples.

\section{Tools and Materials}

The tools used in this research are in the form of tools used in the microbiology laboratory; glassware, sample containers (sterile plastic), ose, pipette, micropipette, scale, eppendorf tube, centrifuge, vortex, glass object, incubator, autoclave, refrigerator, laminary air flow, microscope, Vitek 2 Compact, PCR, electrophoresis and gel doc.

Materials used in research; vegetables, namely cabbage, lettuce, cucumber, basil and long beans. Buffered Listeria Enrichment Broth (BLEB), Blood Agar Plate (BAP), N.AN (Naladixic Acid / Natamycin) supplement, PALCAM Agar solid selective culture medium, Oxford Selective CNCAF supplement, goat blood, SIM agar base, 
GP Card, PCR extraction kit, primer, PCR (Go Taq Green) enzyme, RNAse Free water, Agarose, Ethidium Bromide, TBE 0.5, Loading Dye, DNA Leader / Marker (100 bp), and Gram stain reagent.

\section{Culture on BLEB Media}

The obtained sample was then crushed using a mortal, then weighed as much as 25 grams and then inoculated on BLEB media as much as 225 $\mathrm{ml}$ and incubated for $2 \times 24$ hours at $30^{\circ} \mathrm{C}$. Turbidity on BLEB media indicates bacterial growth.

\section{Culture on Selective Media}

The results of growth on the BLEB media are then directly scratched using ose on the PALCAM agar media. Then incubated at $37^{\circ} \mathrm{C}$ for $2 \times 24$ hours. Colonies were observed, after incubation for 1-2 days, the colony was grayish green and arose, the colony from PALCAM agar was inoculated to the BAP media for hemolysis tests. on the blood media so that the colonies look like creams and mucoid (hemolysis).

\section{Identification of Listeria spp. Fenotype with Vitek}

The results of culture that has been incubated, and there is a target colony, then biochemical tests were carried out using a GP card on the Vitek ${ }^{\circledR} 2$ Compact. The automatic Vitek ${ }^{\circledR}$ 2 Compact system from Biomerieux works on the calorimetric principle for identification, through biochemical and antibiotic sensitivity testing. The accuracy of the Vitek ${ }^{\circledR} 2$ Compact automatic system ranges from 97.8\% (O'Hara, 2005) to 98.02\% (Duggal, et al., 2012).

\section{Identification of Listeria spp. Genotype by Multiplex PCR}

DNA extraction using TIANampp Genomic DNA Kit. Table 1 shows the primers used to detect Listeria spp. (prs) and Listeria monocytogenes (mmo1030). The reaction mixture for PCR is $25 \mu \mathrm{l}$ each set, in which there are $5 \mu \mathrm{INA}$ templates, $12.5 \mu \mathrm{l}$ Go Taq Master Mix, $1 \mu \mathrm{l}$ forward primer and $1 \mu \mathrm{l}$ reverse primer, and the addition of nuclease free water to suffice the mixture to $25 \mu \mathrm{l}$. The PCR cycle refers to Ryu J, et al (2012) using conventional PCR, one cycle for initial denaturation at $94{ }^{\circ} \mathrm{C}$ for 5 minutes, then 35 cycles for denaturation at $94^{\circ} \mathrm{C}$ for 30 seconds, annealing $60{ }^{\circ} \mathrm{C}$ for 30 seconds, and extension at $72^{\circ} \mathrm{C}$ for 30 seconds. and one cycle for the final extension at $72^{\circ} \mathrm{C}$ for 5 minutes. PCR products were analyzed using $0.5 \mathrm{TBE}$ buffer electrophoresis gel at $100 \mathrm{~V}$ voltage for 120 minutes, with a composition of $2 \%$ agarose and $10 \mu \mathrm{l}$ Ethidium Bromide. Use 100bp DNA Marker ladder to see the PCR product band sizes.

\section{Data Analysis \\ Analysis using MS Excel 2010. Percentage of Listeria spp. analyzed by descriptive analysis.}

Tabel 1. Primer pairs sequence and terget gene

\begin{tabular}{|c|c|c|c|c|}
\hline Species & Gene & Primer & Sequens (5'-3') & $\begin{array}{l}\text { PCR product } \\
\text { (bp) }\end{array}$ \\
\hline Genus Listeria & Prs & $\begin{array}{l}\text { prs-F } \\
\text { prs-R }\end{array}$ & $\begin{array}{l}\text { GCTGAAGAGATTGCGAAAGAAG } \\
\text { CAAAGAAACCTTGGATTTGCGG }\end{array}$ & 370 \\
\hline Listeria monocytogenes & Lmo1030 & $\begin{array}{l}\text { Lmo1030-F } \\
\text { Lmo1030-R }\end{array}$ & $\begin{array}{l}\text { GCTTGTATTCACTTGGATTTGTCTGG } \\
\text { ACCATCCGCATATCTCAGCCAACT }\end{array}$ & 509 \\
\hline
\end{tabular}




\section{RESULT AND DISCUSSION}

During the February-June 2019 period, 57 fresh vegetable samples were obtained from traditional market of Makassar City, Indonesia. Table 2 shows the prevalence of Listeria spp. from fresh vegetables samples in Traditional Market, Makassar, Indonesia is $14.03 \%$ (8 of 57 samples). Long bean samples is the highest prevalence of $31 \%$ where there are $4 / 16$ positive samples. Lettuce from 11 samples, both phenotypically and genotypically showed no positive results.

The phenotype test was conducted by referring to FDA testing standards with BLEB as a selective media and PALCAM media as a culture media. Genotypic test using multiplex PCR method with the prs gene as a marker of Listeria $s p p$.

From the results of vitek using a GP card does not show specific bacterial species may be caused by bacteria growing on PALCAM media not contained in the GP card. The culture of Listeria monocytogenes was not identified because the number of bacterial cells did not reach the detection sensitivity, which was $104 \mathrm{CFU} / \mathrm{ml}$. Beumer and Wilma (2003) say that most likely most raw food products will hold Listeria in low quantities. In the case of a low number of Listeria cells, isolation is difficult so inoculation is recommended to test animals, including embryo eggs.

According to Beumer R.R. and Hazeleger W.C. (2003), the success of the culture method depends on several factors. Such as, the number and condition of bacteria in the sample, media selectivity (balance between inhibition of competing bacteria and target bacteria), selection of isolation media (the difference between target bacteria and competitive microflora) and incubation conditions (for example, temperature, time, and oxygen).

Among the 5 types of vegetables, Listeria spp. more dominant in long beans with $31.2 \%$ (5/16). Listeria monocytogenes previously in string beans was isolated by Ponniah J., et al (2010) with a percentage of $31.3 \%(10 / 32)$. In lettuce either through phenotype or genotype testing, eight samples showed negative results from Listeria spp. The results of the study of Jamali H., et al (2013), Listeria monocytogenes isolated from lettuce, only $5.6 \%(1 / 18)$. Overall the results of this study are not much different from the previous findings summarized by Zhu Q. et al (2017) whic was the percentage of Listeria spp. low on lettuce. Figure 1 shows the results on agarose gel electrophoresis using a special primer for the prs gene (370bp).

In all 8 samples with positive prs genes, then back in the PCR using the 1 mo1030 gene as a marker of Listeria monocytogenes to determine whether the sample was contaminated with Listeria monocytogenes bacteria. Species identification is only done using the Imo1030 gene as a marker of Listeria monocytogenes because the only available control is Listeria monocytogenes ATCC 7644. The availability of control of other Listeria species and the difficulty to obtain is a limitation of this study. Positive Listeria monocytogenes isolates were confirmed by PCR test using the lmo1030 gene as primer (Table 3).

All positive Listeria spp. samples found in this study is Listeria monocytogenes. Figure 2 shows the result on agarose gel electrophoresis using primers specific to the lmo1030 gene (509bp) for the isolate, positive and negative control samples. The multiplex PCR method detects Listeria monocytogenes by targeting the prs gene as a marker of the genus Listeria and the Imo1030 gene as a marker of Listeria monocytogenes.

Aznar R. and Alarcón B. (2003) revealed that at least $103 \mathrm{CFU} / \mathrm{g}$ must be present to be detected by PCR after DNA extraction methods.

Based on the results of the examination that Listeria spp. (Listeria monocytogenes) has been detected in fresh vegetables from traditional markets. This indicates that some vegetables that are often consumed in raw conditions may be contaminated by Listeria spp. and therefore can pose health risks. The presence of Listeria monocytogenes in these vegetables is of concern because these various types of vegetables are often consumed with minimal processing, only through washing. 
Tabel 2. The prevalence of Listeria spp. on fresh vegetables from traditional markets

\begin{tabular}{llllll}
\hline \multirow{2}{*}{ No } & \multirow{2}{*}{ Vegetables } & \multirow{2}{*}{ Number of Sample } & \multicolumn{2}{c}{ Identification result } & \multirow{2}{*}{ Phenotype } \\
& Cabbage & 11 & - & 2 & 18,2 \\
\hline 1 & Genotype & Positive samples (\%) \\
2 & Lettuce & 8 & - & - & 0 \\
3 & Basil & 11 & - & - & 0 \\
4 & Cucumber & 11 & - & 1 & 9,1 \\
5 & Long beans & 16 & - & 5 & 31,2 \\
Total & & 57 & 0 & 8 & 14,03 \\
\hline
\end{tabular}

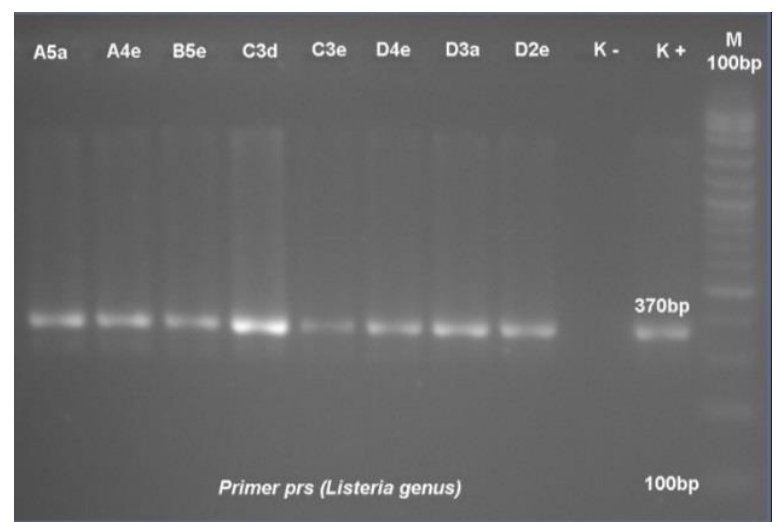

Figure 1. Multiplex PCR results of the prs gene as a marker for the genus Listeria from vegetable samples

Table 3. Electrophoresis results of PCR gene lmo1030 in 8 positive samples of Listeria spp.

\begin{tabular}{ccc}
\hline No. & Kode Sampel & Listeria spp. \\
\hline 1 & D2e & Listeria monocytogenes \\
2 & D3a & Listeria monocytogenes \\
3 & D4e & Listeria monocytogenes \\
4 & C3e & Listeria monocytogenes \\
5 & C3d & Listeria monocytogenes \\
6 & B5e & Listeria monocytogenes \\
7 & A4e & Listeria monocytogenes \\
8 & A5a & Listeria monocytogenes \\
\hline
\end{tabular}

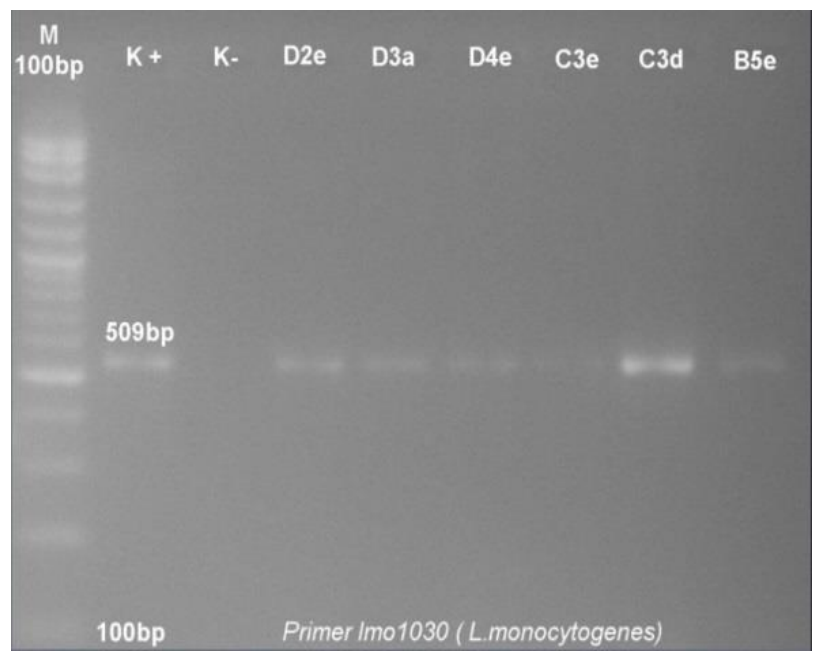

Figure 2. Multiplex PCR results of the Imo1030 gene as a marker for Listeria monocytogenes from vegetable samples. 
According to Salvat G. and Fravalo P. (2004), if Listeria monocytogenes in food is at least 1 $\mathrm{CFU} / 100 \mathrm{~g}$ it can cause food insecurity in 32 days, whereas $10 \mathrm{CFU} / \mathrm{g}$ can cause food insecurity in 8 days. Listeria monocytogenes is able to grow in the temperature range of about -0.4 to $45^{\circ} \mathrm{C}$ with an optimal temperature of $37^{\circ} \mathrm{C}$. Therefore, this can cause the prevalence of $L$. monocytogenes in food to increase and reach unsafe levels during the storage period. The dose of $L$. monocytogenes infection for healthy or vulnerable individuals has not been established, however, it is estimated that 107-109 CFU in healthy individuals and 105-107 CFU in susceptible individuals such as people with immune disorders or pregnant women.

Supervision of vegetables consumed raw against the threat of pathogenic microbes is important. Moreover, we do not know the path of contamination of Listeria monocytogenes bacteria to food to be consumed. One form of prevention is not to use the same cutting board or knife to prepare raw meat and vegetables, wash hands regularly, wash vegetables, fruit and meat under running water

\section{CONCLUSION}

Our study has shown that prevalence of Listeria spp. with prs genes in fresh vegetables from traditional markets of Makassar City, Indonesia is eight of fifty seven (14\%). All Listeria species found in this study is Listeria monocytogenes. We also provide information and additional data that prs genes can be used as screening genotype for identify Listeria species in fresh vegetables. Therefore, further study is needed with more number and types of vegetables to identify Listeria $s p$.

\section{ACKNOWLEDGMENTS}

The authors thank the laboratory staffs from Hasanuddin University Teaching Hospital, Makassar for laboratory assistance. This study would not been possible without enthusiastic cooperation of participants.

\section{REFERENCES}

Aznar R. and Alarcón B. (2003). PCR detection of Listeria monocytogenes: a study of multiple factors affecting sensitivity. Journal of Applied Microbiology. 95: 958-966. [DOI: 10.1046/j.1365-2672.2003.02066.x].

Barocci, S., Calza, L., Blasi, G., Briscolini, S., Curtis, M. D., Palombo, B., Cucco, L., Postacchini, M., Sabbatini, M., Graziosi, T., Nardi, S., Pezzotti, G. (2008). Evaluation of a rapid molecular method for detection of Listeria monocytogenes directly from enrichment broth media. Food Control. 19: 750-756.

Beumer R.R. and Hazeleger W.C. (2003).Listeria monocytogenes: diagnostic problems. FEMS Immunology and Medical Microbiology. 35(3): 191197. [DOI: 10.1016/S0928-8244(02)00444-3].

Dandapani S., Mary M.S., Mahamuni D., Rengaraj C. (2011). Occurrence of Listeria monocytogenes in Food and Ready to Eat Food Products Available in Tiruchirappalli, Tamil Nadu, India. World Journal Life Science and Medical Research. 1(4): 70.

Doumith, M., Buchrieser, C., Glaser, P., Jacquet, C., \& Martin, P. (2004). Differentiation of the major Listeria monocytogenes serovars by multiplex PCR. Journal of Clinical Microbiology. 42: 3819-3822.

Duggal, S., R. Gaind, N. Tandon, M. Deb, and T. Das Chugh. (2012). Comparison of an automated system with conventional identification and antimicrobial susceptibility testing. International Scholarly Research Network Microbiology. 2012. doi:10.5402/2012/107203.

European Food Safety Authority. (2013). Analysis of the baseline survey on the prevalence of Listeria monocytogenes in certain ready-to-eat (RTE) foods in the EU, 2010-2011 Part A: Listeria monocytogenes prevalence estimates. EFS A Journal. 11: 3241 .

Jamali H., Chai L.C., Thong K.L. (2013). Detection and isolation of Listeria spp. and Listeria monocytogenes in ready-to-eat foods with various selective culture media. Food Control. 32; 19-24. [DOI: 10.1016/j.foodcont.2012.11.033].

Mazza R., Piras F., Ladu D., Putzolu M., Consolati S.G., Mazette R. (2015). Identification of Listeria spp. strains isolated from meat product and meat production plants by multiplex polymerase chain reaction. Italian Journal of Food Safety. 4(4):5498. [DOI: 10.4081/ijfs.2015.5498].

O'Hara, C. M. (2005). Manual and automated instrumentation for identification of enterobacteriaceae and other aerobic gramnegative bacilli. Clinical microbiology reviews. 18: 147-162. doi:10.1128/CMR.18.1.147 
Pesavento G., Ducci B., Nieri D., Comodo N., Nostro A.L. (2010). Prevalence and antibiotic susceptibility of Listeria spp. isolated from raw meat and retail foods. Food Control. 21: 708-713.

Ponniah J., Robin T., Paie M.S., Radu S., Ghazali F.M., Kqueen Y.K., et al. (2010). Listeria monocytogenes in raw salad vegetables sold at retail level in Malaysia. Food Control. 21: 774-778. [DOI: 10.1016/j.foodcont.2009.09.008].

Prahesti K.I., Mayasari N.L.P.I., Malaka R., Yuliati F.N., Pasaribu F.H. (2017). Isolation and Identification of Listeria monocytogenes from Raw Milk in Enrekang District South Sulawesi. Acta Veterinaria Indonesiana. 5(2):57-65.

Ryu J, Park SH, Yeom YS, Shrivastav A, Lee SH, Kim Y-R, Kim H-Y, (2013). Simultaneous detection of Listeria species isolates from meat processed foods using multiplex PCR. Food Control 32:65964.
Salvat G. and Fravalo P. (2004). Risk assessment strategies for Europe: integrated safety or final product control: example of Listeria monocytogenes in processed products from pork meat industry. Dtsch Tieraratl Wochenschr. 111(8):331-4.

Scallan, E., Griffin, P. M., Angulo, F. J., Tauxe, R. V., \& Hoekstra, R. M. (2011). Foodborne illness acquired in the United States-unspecific agents. Emerging Infectious Diseases. 17: 16-22.

Sugiri Y.D., Kleer J., Golz G., Meeyam T., Chaisowwong W., Alter T. (2014). Prevalence and antimicrobial susceptibility of Listeria monocytogenes in fresh poultry products in Bandung, Indonesia. Journal of Food Protection. 77(8): 1407-1410.

Zhu Q., Gooneratne R., Hussain M.A. (2017). Listeria monocytogenes in Fresh Produce: Outbreaks, Prevalence and Contamination Levels. Foods. 6(21). [DOI: 10.3390/foods6030021]. 